UDC [624.072.33:624.011.1]:512.547.2

D.V. Mikhaylovskiy ${ }^{1}$, PhD, Assoc.Prof.,

D.M. Matyuschenko ${ }^{2}$, Senior Engineer

${ }^{1}$ Kyiv National University of Construction and Architecture, 31 Povitroflotsky Ave., 03680 Kyiv, Ukraine

${ }^{2}$ JSC "Ukrbudproekt”, 5-B Aviakonstruktora Antonova Str., 03031 Kyiv, Ukraine; e-mail: matyuschenko.ubp@ gmail.com

\title{
NUMERICAL RESEARCHES OF DGRP-TYPE EXPERIMENTAL FRAMES USING THE FINITE ELEMENTS METHOD
}

\begin{abstract}
Д.В. Михайловський. Д.М. Матющенко. Чисельні дослідження експериментальних рам типу ДГРП за допомогою методу скінченних елементів. Одним 3 найрозповсюдженіших типів конструкцій 3 клеєної деревини є гнутоклеєні рами. 3 використанням гнутоклеєних рам побудовано багато споруд промислового і громадського призначення. Використання таких рам в спорудах 3 агресивним середовищем показало велику надійність. Однак, при всіх перевагах гнутоклеєних рам 3 клеєної деревини їх застосування стримується недосконалістю методик розрахунку напружень, які базуються на принципах розрахунку конструкцій з цільної деревини. Потреба ретельного дослідження і удосконалення методик розрахунку гнутоклеєних рам обумовлює актуальність теми дослідження. Мета: Метою роботи є чисельні дослідження експериментальних рам з подальшим вдосконаленням методик розрахунку напружень в карнизних вузлах гнутоклеєних рам. Матеріали $\boldsymbol{i}$ методи: Для досягнення поставленої мети було проведено теоретичне визначення переміщень і компонент напруженого стану з використанням експериментальних пружних характеристик матеріалу рам. Клеєна деревина в порівнянні з цільною ближча до транстропної розрахункової схеми симетрії, згідно з якою механічні і пружні властивості будівельного матеріалу в площинах, перпендикулярних напрямку вздовж волокон деревини, є еквівалентними. Для достовірного визначення параметрів напружено-деформованого стану в елементах будь-якого обрису, отримання якісної картини розподілу напружень по всій довжині рами і встановлення закономірності зміни напружень у складі всієї конструкції було використано програмний комплекс ЛІРА-САПР, в якому було реалізовано модель ортогональної анізотропії (ортотропії) в пластинчастих скінченних елементах. Результати: Аналізуючи отримані результати, можна зробити висновок, що в цілому збіг між теоретичними і експериментальними даними є задовільним. Можна стверджувати, що деформований стан рам, отриманий теоретичним розрахунком 3 врахуванням дійсних фізико-механічних характеристик матеріалу експериментальних конструкцій, $є$ достовірним. Враховуючи те, що в стиснуто-згинальних елементах додатковий згинальний момент від нормальної сили є функцією переміщень, можна вважати, що даний розрахунок за методом скінченних елементів в ПК ЛІРА-САПР дозволяє цілком задовільно визначати напруження з врахуванням деформованої схеми рам і анізотропії фізико-механічних властивостей клеєної деревини.
\end{abstract}

Ключові слова: гнутоклеєна рама, клеєна деревина, карнизний вузол, напружено-деформований стан, метод скінченних елементів.

D.V. Mikhaylovskiy, D.M. Matyuschenko. Numerical researches of DGRP-type experimental frames using the finite elements method. One of the most common types of structures made of glulam beams is curved frames. A lot of industrial plants and public buildings are built using curved frames. The using of such frames in buildings with an aggressive environment showed their great reliability. However, with all the advantages of curved frames with glulam beams their using is constrained by imperfect methods of stress analysis based on the principles of calculation of structures with solid wood. The need for careful study and improvement of methods of calculation of Curved frames determines the relevance of researched topic. Aim: The aim of this research is to study the numerous researches of pilot frame for further improving of methods of stress analysis in the cornice nodes of curved frames. Materials and Methods: In order to achieve this goal the theoretical displacements and component stress state were determined using experimental elastic characteristics of the frames material. Glulam beams compared to a solid closer to trans tropic design scheme of symmetry, according to which the mechanical and elastic properties of building materials in planes perpendicular direction along the wood fibers are equivalent. For reliable determination of the parameters of the stress-strain state in the elements of any shape, getting of quality pictures of stress distribution along the length of the frame and establishing patterns of changes in stress in the composition of the assembly, the software system LIRA-CAD has been used , where a model of orthogonal anisotropy (orthotropy) in the plate finite elements has been realized. Results: Analyzing the results, we can conclude that the overall coincidence between theoretical and experimental data is satisfactory. Arguably, the strained state of frames obtained by theoretical calculation with taking into account the real physical and mechanical characteristics of the experimental designs material is significant. Given that in the compressed-bending elements the additional bending moment on the normal force is a function of movement, we can assume that this calculation method of finite elements in LIRA-CAD allows satisfactorily determine the tension in view of the deformed circuit frames and anisotropy of physical and mechanical properties of glulam beams.

Keywords: curved frame, glulam beams, cornice node, stress-strain state, finite elements method.

Introduction. Experimental studies and operating experience of Curved frames with glulam beams show that cornice node is the most dangerous place in the frame and the reliability of whole construction depends on its reliability[1...4].

\section{DOI 10.15276/opu.2.49.2016.04}

(C) 2016 The Authors. This is an open access article under the CC BY license (http://creativecommons.org/licenses/by/4.0/). 
To ensure the reliability of frame structures with glulam beams is important to have a precise method of determining of stresses component of the stress state. Given that glulam beams are anisotropic materials, the problem of determining the stress component of the stress state is extremely important.

Existing methods of stress analysis are different and are inaccurate. So important is the development of precision engineering techniques of stress analysis, which will to formulate the conditions under which the compatible component actions of the stress state will be considered.

Methods of stress analysis that occur in the cornice nodes of curved frames somewhat limited. In the regulations [5, 6] and publications [7...9] there are methods and recommendations proposed that can make certain assumptions about the a stressful state in cornice nodes of curved frames, but they do not take into account the distribution of stress in height section of curved frames and questionable about the legality of their use for these types of frames.

The aim of this research is to study the numerous researches of pilot frame for further improving of methods of stress analysis in the cornice nodes of curved frames.

Materials and Methods. To achieve this purpose it was the theoretical determination of displacements and component of stress state (normal stresses along the grain $\sigma_{x}$, normal stresses across the grain $\sigma_{y}$ and pinned stress $\tau_{x y}$ ).

For reliable determination of the parameters of the stress-strain state in the elements of any shape, getting of quality pictures of stress distribution along the length of the frame and establishing patterns of changes in stress in the composition of the assembly, the software system LIRA-CAD has been used, where a model of orthogonal anisotropy (orthotropy) in the plate finite elements has been realized.

Hereinafter, we conducted the comparison of the theoretical results with experimental data of tests of curved frames with rack-cornice block presented in [10].

It was introduced the following elastic constants: elastic modulus parallel to grain $\mathbf{E}_{\mathbf{0}}$, modulus of elasticity across the grain $\mathbf{E}_{\mathbf{9 0}}$, shear modulus $\mathbf{G}_{\mathbf{0}}$, Poisson coefficient $\mu_{90.0}, \mu_{0.90}$, which are determined on specimens made of glulam beams of frames after the test.

When calculating the problems in mechanics of solid deformable anisotropic body an important issue is the choice of the calculation model of environment that establishes the nature of the change of elastic and strength characteristics depending on the direction of the major axes of symmetry.

Well known that for the glulam beams the scheme of orthogonal anisotropy, i.e. the presence of three mutually perpendicular planes of symmetry [11...13] is characterized. This structural symmetry planes are the planes perpendicular to the normal direction along the fiber, the radial and tangential directions across the fibers.

Properties of solid wood are determined by its structure, namely the different orientation of annual layers for radial and normal directions, as well as the width and content of medullar rays, but building elements of considerable size, made of wood, characterize the random orientation of annual layers in relation to their faces and not coincides with the radial and normal directions.

The structure of glulam beams compared to solid wood is more order. Therefore for building structures made of glulam beams the anisotropy even more strong than for the solid. As glulam beams components made of a set of boards that have a random orientation of the annual layers relative to the side surfaces, the elastic properties of glulam beams in the direction perpendicular to the axis of the glulam package is averaged, and can be considered as equivalent.

So on the basis of [12...15] Considering the above, we can conclude that glulam beams compared to solid wood closer to trans tropic calculation scheme of symmetry, according to which the mechanical and elastic properties of building materials in planes perpendicular direction along the fiber wood are equivalent.

For the calculation of the experiment in program complex LIRA-CAD a model of orthogonal anisotropy (orthotropy) in the plate finite elements was implemented. This allows reliably determine the parameters of the stress-strain state in the elements of any shape, get a good picture of stress distribution along the length of the frame and install the patterns of stress changes in the composition of the whole structure.

When calculating the following assumptions have been taken: 
1) Work timber is considered only in elastic deformation stage;

2) The functional relationship between stresses and deformations described by generalized Hooke's law for transtropic body;

3) Stress-strain state is subject to the hypothesis planar sections;

4) Finite elements are rectangles.

The geometry of the studied frames described by coordinates of mesh nodes for external and internal contours in the direction of both axes $X$ and $Z$. Discretization of construction by altitude is automatically performed after setting the number of required partitions.

Calculated loading is applied was concentrated forces acting on objects of research in grid nodes under the partition. Calculated loading and location of meshes performed by scheme of testing installation described in [10] in detail. Calculated cross sections for which tensions were determined shown in Fig. 1.

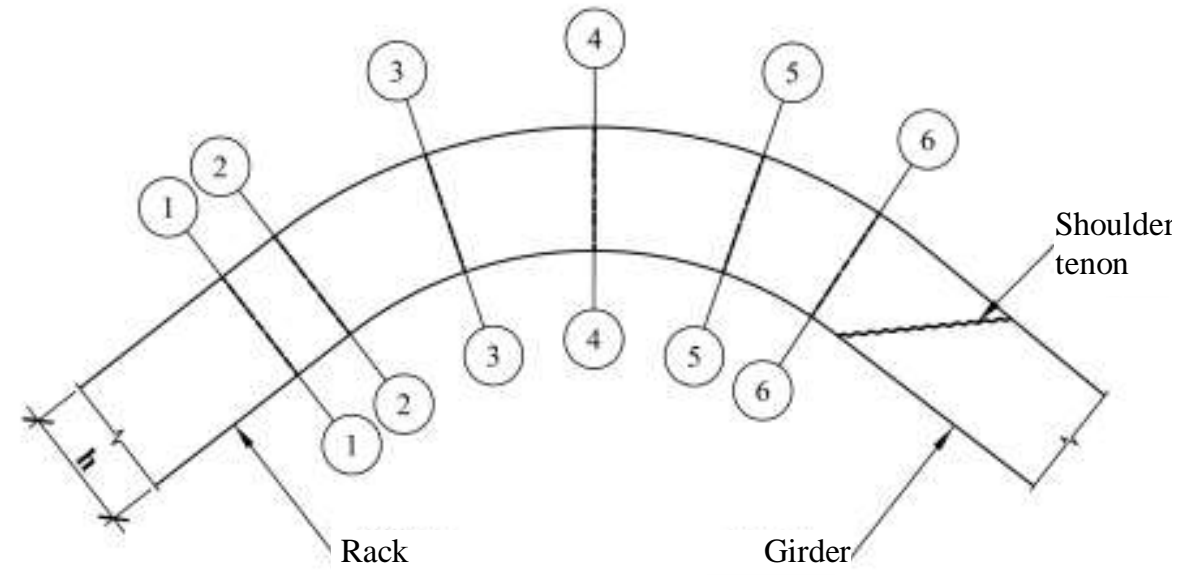

Fig. 1. Scheme of calculation sections location in the cornice node of curved frames DGRP-5 and DGRP-6

The calculation was has been made using plate-type elements 41 and 44 according classifier LIRA-SAPR 2013. Parameters of glue seam are adopted identical to wood and regarded as components of finite elements. The influence of elastic-plastic properties can be ignored. The maximum size of the finite element in calculation schemes of experimental frames is not exceeding $16 \times 8 \mathrm{~mm}$ in the front, $8 \times 8 \mathrm{~mm}$ in curved part and $8 \times 5 \mathrm{~mm}$ in rectilinear girders. Thus, each layer (lamella) has a thickness of $8 \mathrm{~mm}$ in rack-cornice block and $5 \mathrm{~mm}$ in comb-shaped node.

Finite elements were provided with orthogonally anisotropic (orthotropic) properties with the following experimental parameters: modulus of elasticity along the fiber $E_{x}=1407930.683 \mathrm{t} / \mathrm{m}^{2}$, modulus of elasticity across the fibers $E_{z}=57675.841 \mathrm{t} / \mathrm{m}^{2}$, Poisson coefficient $\mu_{z x}=0.429$, $\mu_{x z}=0.017$, density of wood $\rho=0.52 \mathrm{t} / \mathrm{m}^{3}$.

The supporting node of the frames simulated with plate elements of the same type as the frame, but with isotropic properties of materials (steel and plywood). For steel, elastic modulus $E=2.1 \cdot 10^{7} \mathrm{t} / \mathrm{m}^{2}$, Poisson coefficient $\mu=0.3$, density $\rho=7.85 \mathrm{t} / \mathrm{m}^{3}$; for plywood pad, elastic modulus $E=6 \cdot 10^{4} \mathrm{t} / \mathrm{m}^{2}$, Poisson coefficient $\mu=0.065$, density $\rho=0.7 \mathrm{t} / \mathrm{m}^{3}$.

When modeling of supporting and comb-shaped nodes construction the basic principle was to ensure hinge properties to order thereby to approximate the design scheme to testing installation. In supporting node there was supporting metal plate modeled with thickness of $8 \mathrm{~mm}$, which is fixed by the central script on axes $Z$ and $Y$. There has been modeled the plywood pad of size $80 \times 20 \mathrm{~mm}$, through which thrust (axial load) was passed.

To ensure hinge properties in the comb-shaped node the metal part was modeled, on which the transverse force operates and providing free turn of crossbar ends. In purlins fastening places it was set ties along the axis $Y$. 
For modeling of loading which is applied gradually in increments of $25 \%$ from the estimated loading according to [16] there was used the subsystem of LIRA-CAD program "Installation Plus". This made it possible to take into account the deformation of calculation scheme under the influence of its own weight with equipment placed on it. For conventional zero of displacement there was adopted their own frame weight with test equipment.

One of the criteria of reliability of using the method calculation of curved frames considering geometric nonlinearity is the coincidence of theoretical and experimental forms of curved axes. Shown in Fig. 2 and 3 the curves of deformed frames axes built for two series and show their identity forms. Identified theoretical value of movements for most sections are slightly larger than the experimental.

Comparison of values (Fig. 2 and 3) for frames of series DGRP-5 and DGRP-6 showed that their difference is within $6 \%$, excluding the reduction of local movements in the area to comb-shaped node for frame of series DGRP-6.

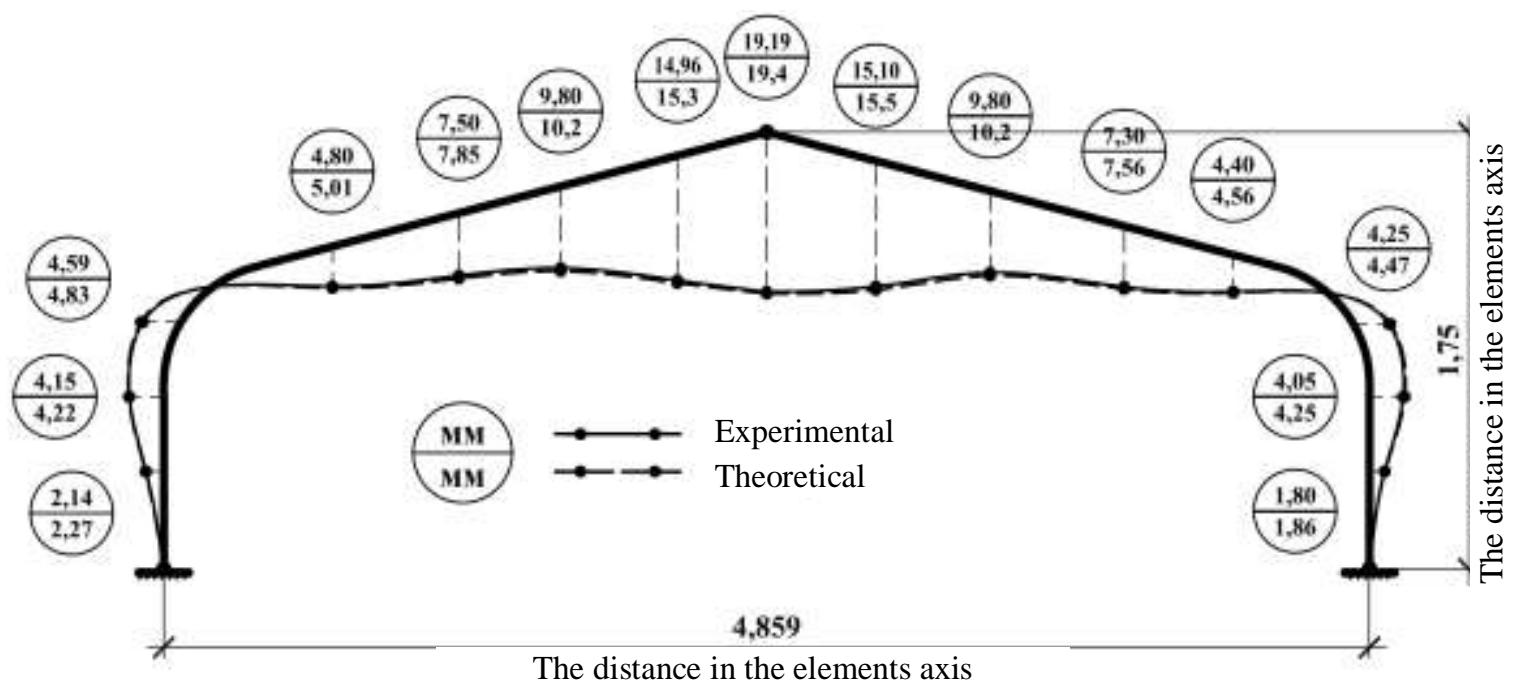

Fig. 2. Theoretical and experimental displacements of frames DGRP-5

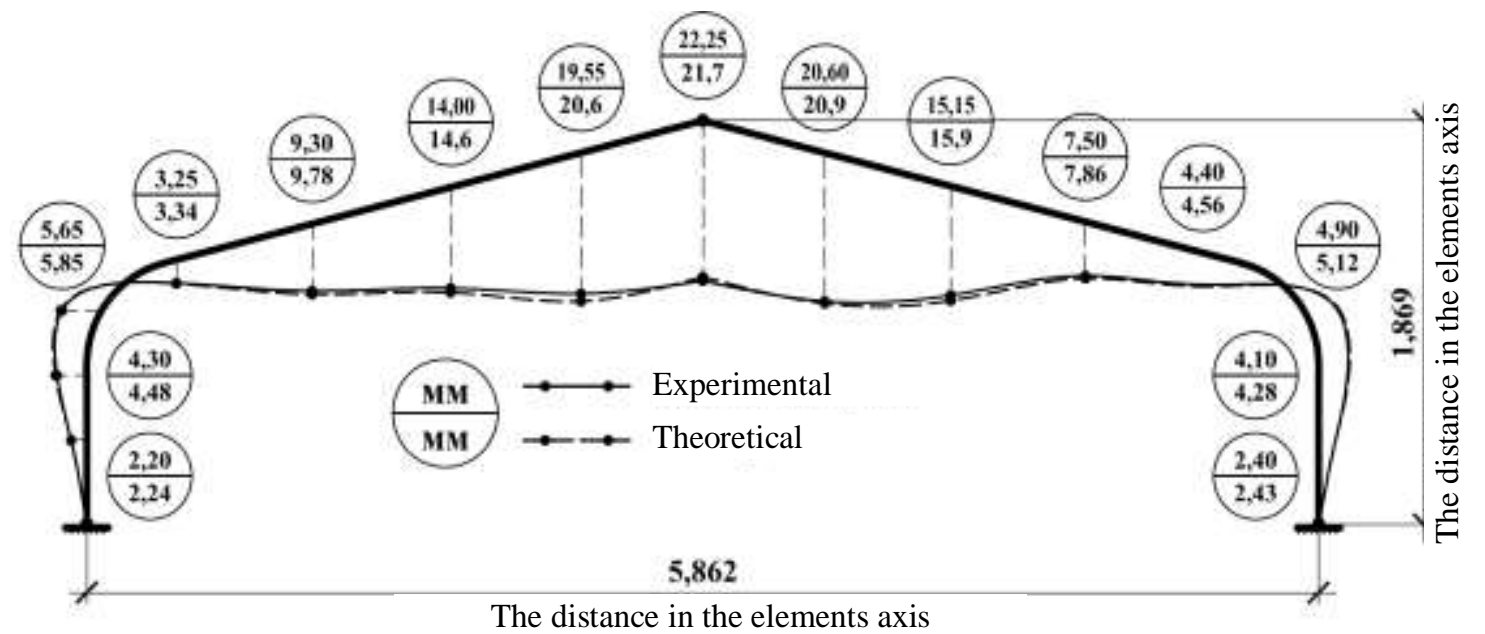

Fig. 3. Theoretical and experimental displacements of frames DGRP-6

Fig. $4 \ldots 9$ show the diagrams of tension $\sigma_{x}, \sigma_{y}$ and $\tau_{x y}$ in curved $(5,4,3)$ and transient $(6,2,1)$ areas of cornice node. 


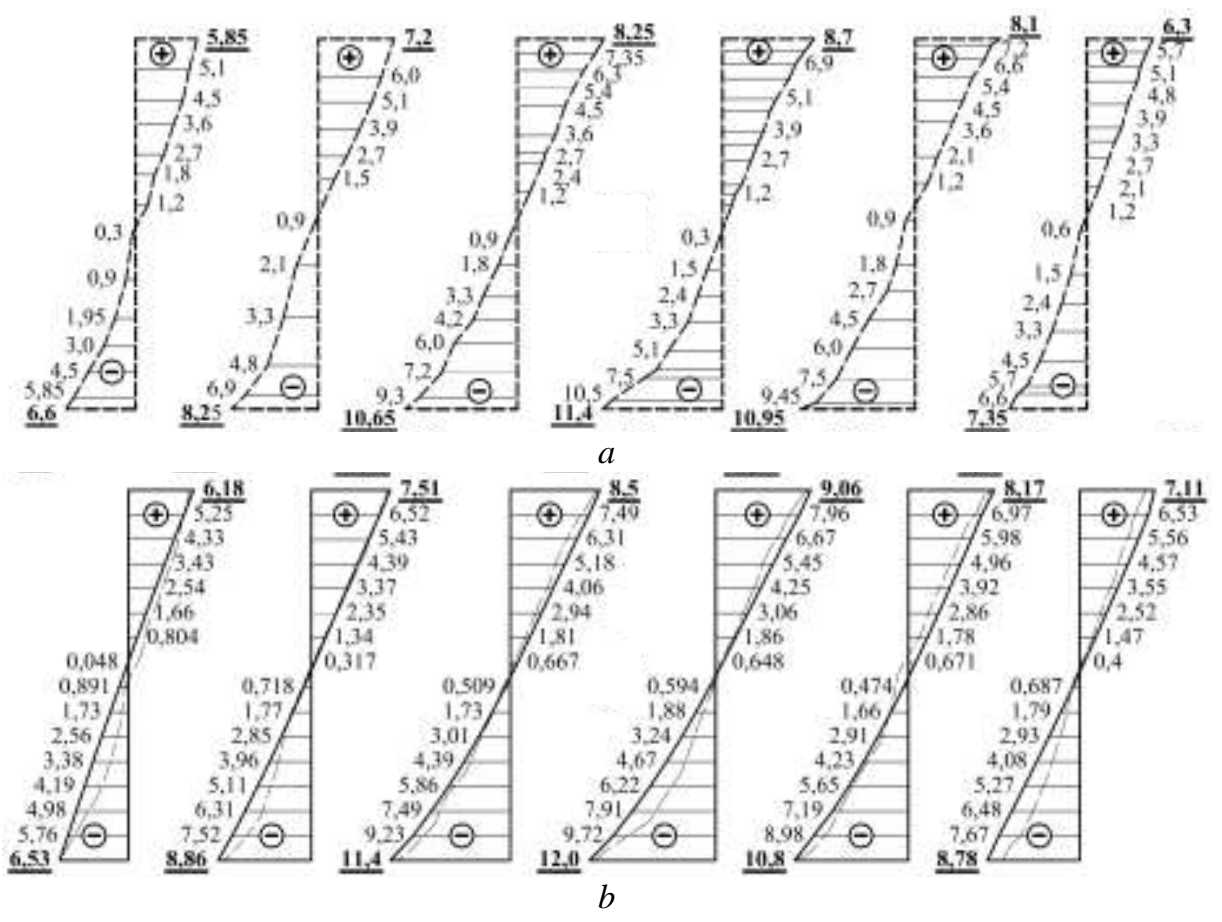

Fig. 4. Diagrams of normal tensions along the fibers $\sigma_{x}$ in a rack-cornice block for frame DGRP 5: $a$-experimental; $b$ - theoretical
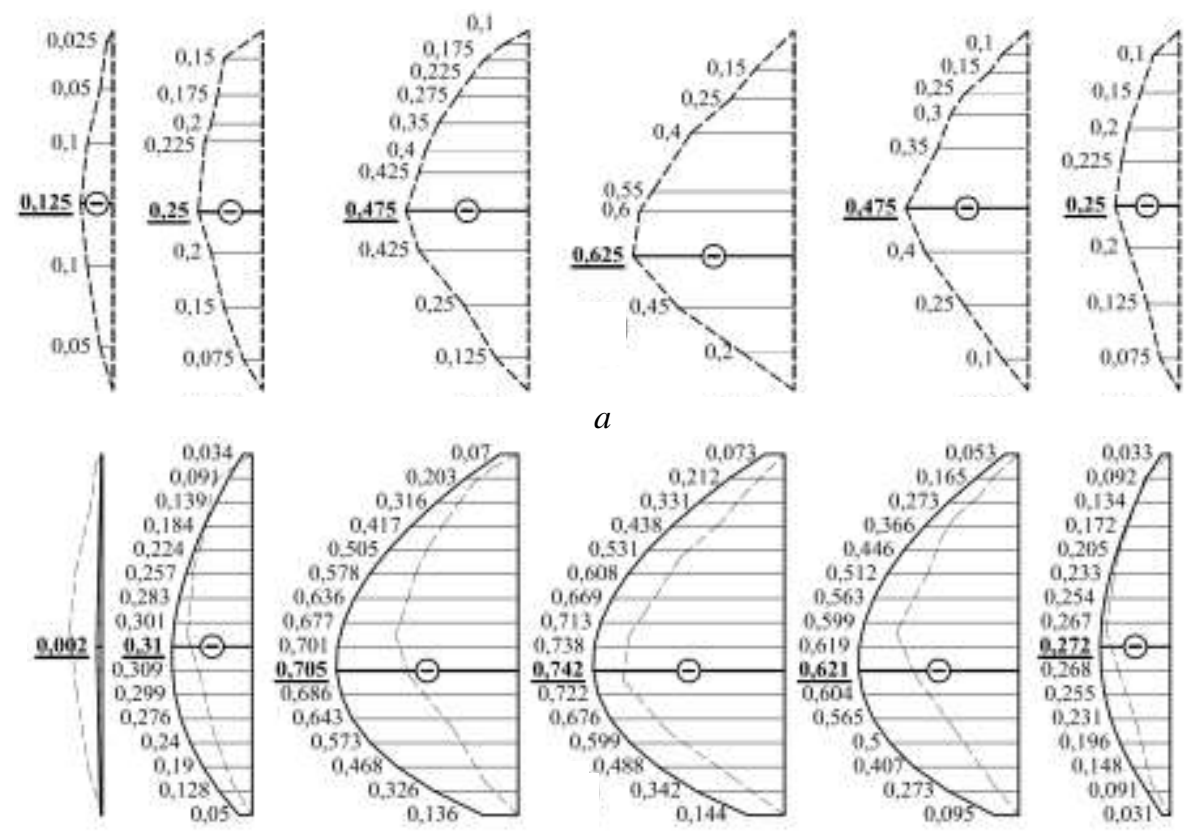

$b$

Fig. 5. Diagrams of normal tensions across the fibers $\sigma_{y}$ in a rack-cornice block for frame DGRP 5: $a$-experimental; $b$ - theoretical 

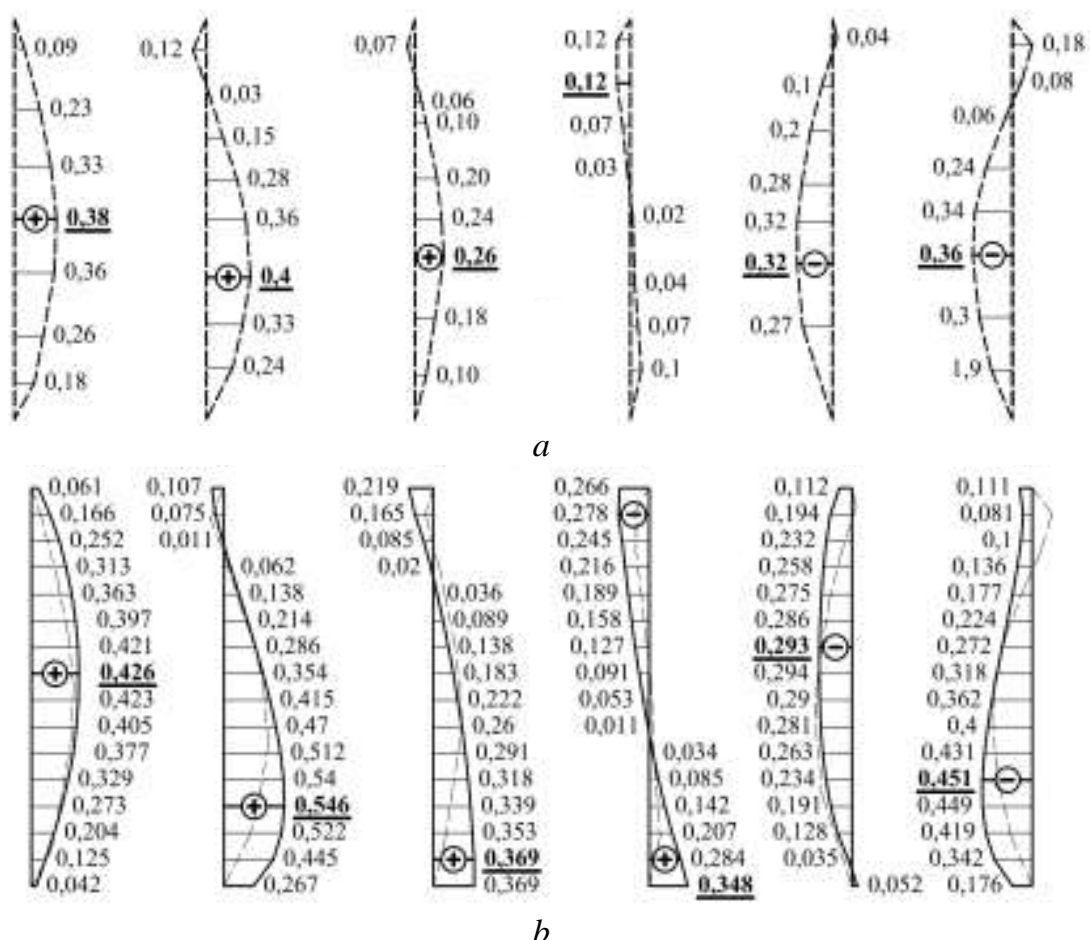

Fig. 6. Diagrams of pinned tension $\tau_{x y}$ in a rack-cornice block for frame DGRP-5: $a$-experimental; $b$ - theoretical

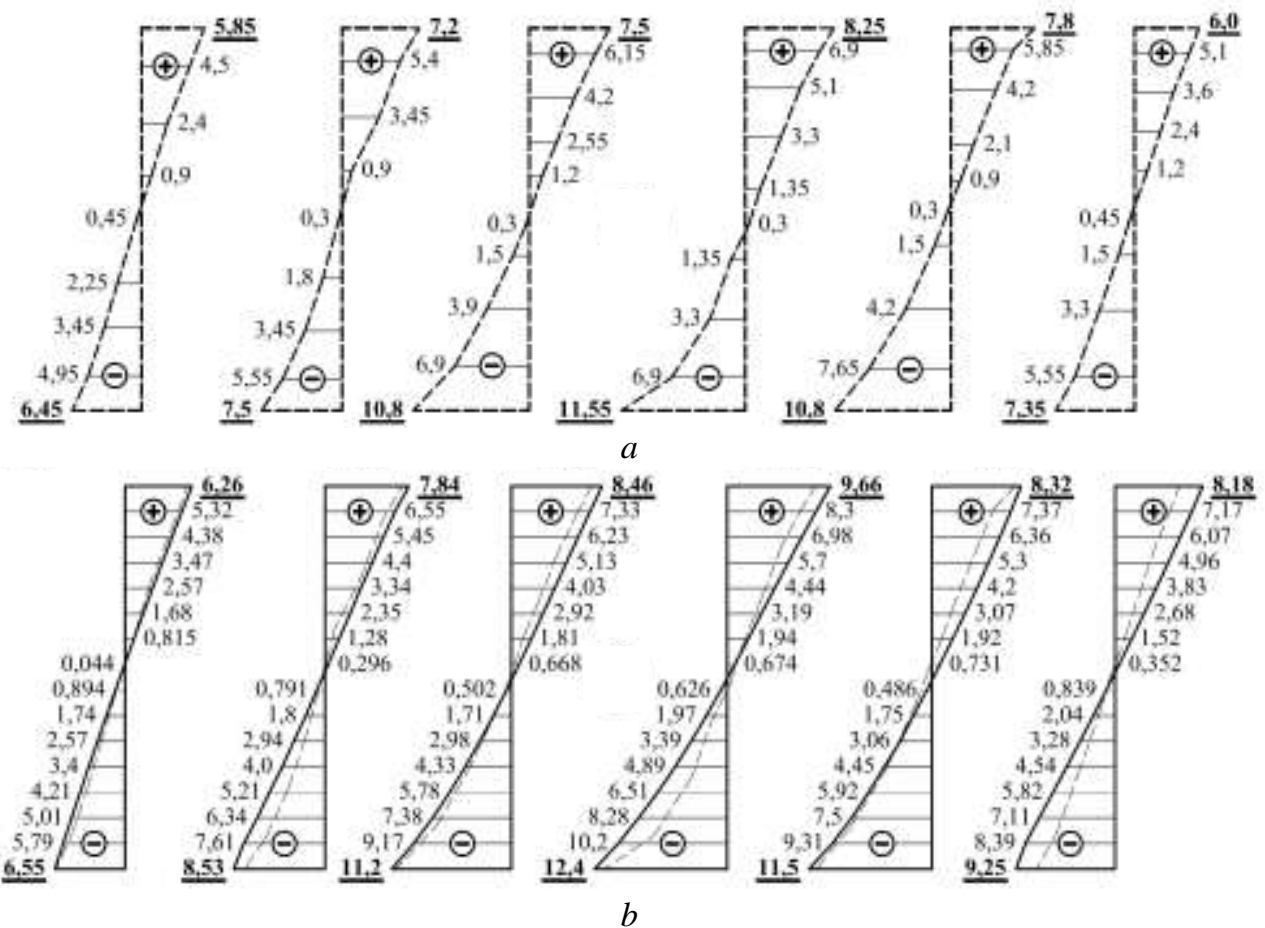

Fig. 7. Diagrams of normal tensions along the fibers $\sigma_{x}$ in a rack-cornice block for frame DGRP-6: $a$-experimental; $b$ - theoretical 

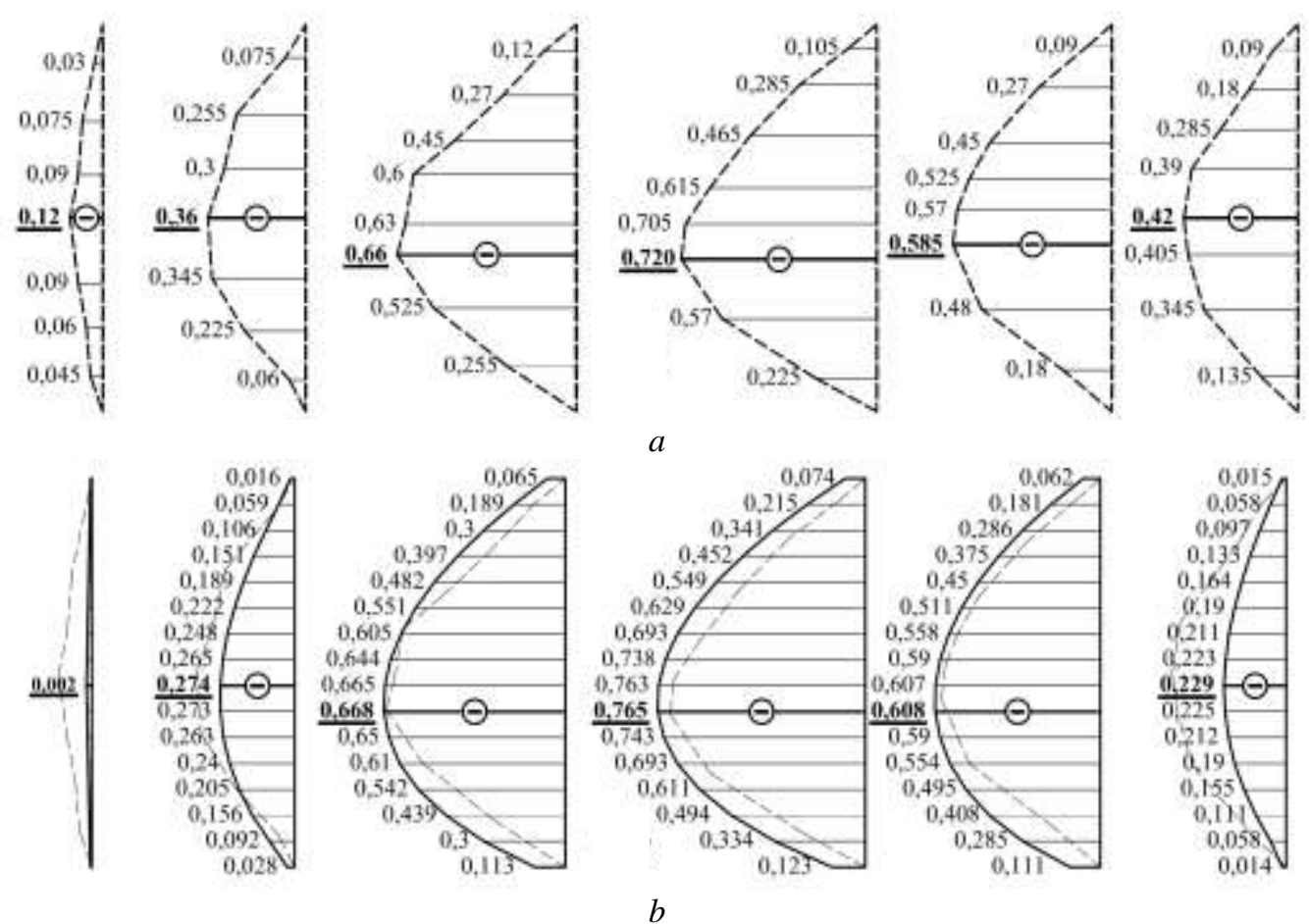

Fig. 8. Diagrams of normal tensions across the fibers $\sigma_{y}$ in a rack-cornice block for frame DGRP-6: $a$-experimental; $b$ - theoretical
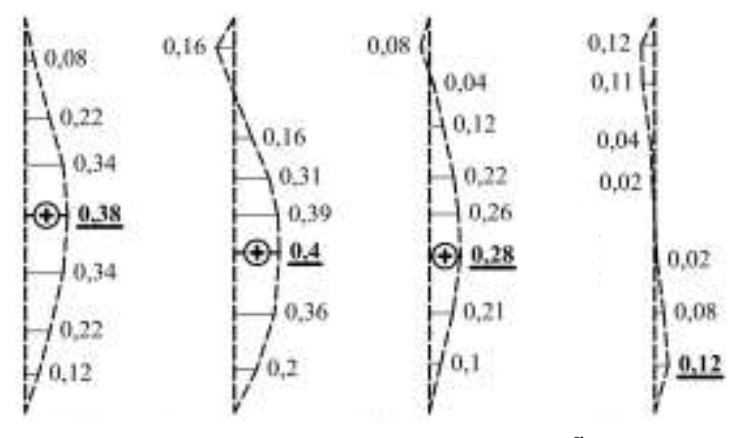

$a$
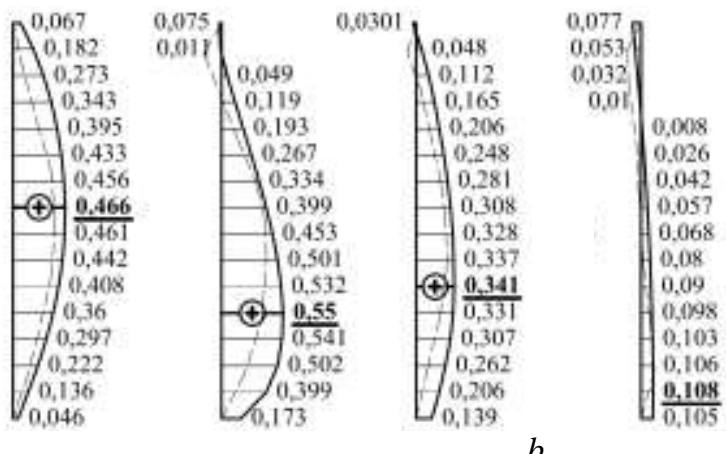
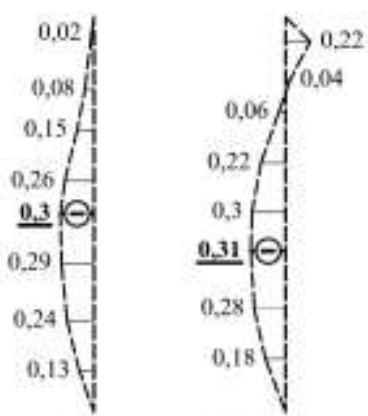

Fig. 9. Diagrams of pinned tensions $\tau_{x y}$ in a rack-cornice block for frame DGRP-6:

$$
a \text { - theoretical; } b \text {-experimental }
$$


The local increase of displacement in frame DGRP-6 in the comb-shaped node may be associated with a possible shift of the supporting and comb-shaped hinges and plywood pad, which perceives the spacing in the supporting node.

Analyzing all the presented results we can conclude that the overall coincidence between theoretical and experimental movement is satisfactory. We can therefore say that the strained state of frames obtained by theoretical calculation and taking into account the real physical and mechanic al characteristics of the material experimental designs is significant.

Given that in the compressed-bending elements the additional bending moment from normal force is a function of movement, we can assume that this calculation method of finite elements in program complex LIRA-CAD allows satisfactorily determine the tension in view of the deformed scheme of frames and anisotropy of physical and mechanical properties of glulam beams.

Comparison of theoretical and experimental values of tensions was performed by comparing the stress diagram $\sigma_{x}, \sigma_{y}$ and $\tau_{x y}$ in sections, which were equipped with strain gauges.

In experimental diagrams at some points local breaks were observed that are caused by local wood defects or local defects, come to the surface, cut fibers, loose wood core and other wood structure homogeneities.

Comparison of theoretical and experimental curves (Fig. 4...9) distribution of all three components of plane stressed state both in length and height section indicates that they are close enough.

The magnitude of the theoretical values $\sigma_{x}$ were slightly higher experimental. On the stretched edge a difference is $1 \ldots 17 \%$, and compressed $-1 \ldots 14 \%$. At points in height section also were observed some differences (mainly in the compressed area of curved areas) not exceeding $0.17 \mathrm{~h}$, where $h$ is height section.

From the stress analysis the most intense stress fibers boundary zone section, compressed and stretched zone are identified. Theoretical value $\sigma_{y}$ slightly higher the experimental also. The difference between them is $1 . .19 \%$, the biggest difference is observed in transitional areas of cornice node that can be attributed to strong heterogeneity and anisotropy of physical and mechanical properties of wood.

As for tangential stresses $\tau_{x y}$ the theoretical data exceeding over the experimental within $5 . .20 \%$ also and only in some points of section 1, 2, 4, where diagrams are alternating in nature preferably, the experimental values are increasing compared to theoretical. It should be noted that the heterogeneity structure of the adhesive package significantly affects on difference of experimental data from theore tical as well as that the angle of displacement of glulam beams $\gamma_{x y}$ is variable, depending on the degree of fluctuations in the values and $\varepsilon_{0}$ and $\varepsilon_{90}$.

Particular attention attracts the fact that malfunctioning of supporting hinge placement and plywood pad in experimental frames that perceive and vertical anchors effort affect on the magnitude of stress significantly.

Conclusions. Analyzing the results of a comparison of experimental and theoretical data we noted that in general, in the examined constructions full quality compliance experimental and theore tical pictures of stress strain state is observed.

This allow to apply the new design principles [17] of glulam beams structures, the main of which is the principle of a precise definition of stress along the grain, across the grain and tangents in view of anisotropy of physical and mechanical properties of materials and joint action of all existing stresses in a dangerous place. This approach, according to the authors, will ensure reliability and safety of curved frames in general as a form of building structures.

\section{Література}

1. Богданова, Е.Н. Анализ причин обрушения зданий и сооружений методы усиления конструкций: обзор.-аналит. докл. / Е.Н. Богданова. - М.: ВНИИНТПИ, 2004. — 96 с. 
2. Matiuschenko, D.M. Experimental and numerical investigations of glulam frames of glued wood / D.M. Matiuschenko // Чернігівський науковий часопис. Серія 2, Техніка і природа. — 2012. № 1(3). - C. 92-99.

3. Кліменко, В.3. Вітчизняний досвід впровадження в капітальному будівництві конструкцій 3 клеєної деревини. Здобутки і проблеми / В.З. Кліменко // Будівництво України. — 2009. — № 5. - С. 17-21.

4. Михайловський, Д.М. Напружений стан гнутоклеєних рам з врахуванням анізотропії фізикомеханічних властивостей клеєної деревини / Д.В. Михайловський, Д.М. Матющенко // Строительство, материаловедение, машиностроение. - 2015. - Вып. 81. - С. 124-129.

5. ДБН В.2.6-161:2010. Конструкції будинків і споруд. Дерев'яні конструкції. Основні положення. Чинний від 2011-09-01. - К.: Мінрегіонбуд України, 2011. - 102 с.

6. EN 1995-1-1:2004. Eurocode 5: Design of timber structures - Part 1-1: General - Common rules and rules for buildings. - Approved: April 16, 2004. - Brussels: European Committee for Standardization, 2004. - $121 \mathrm{p}$.

7. Найчук, А.Я. Некоторые особенности расчета клееных деревянные конструкций / А.Я. Найчук, Е.Н. Серов, И.Ф. Захаркевич // Сб. науч. тр. Междунар. симпозиума «Современные металлические и деревянные конструкции (нормирование, проектирование и строительство)», 15-18 июня 2009 г., Брест, Беларусь. - Брест: ОАО «Брестская типография», 2009. — С. $205-211$.

8. Ormarsson, S. Moisture-induced stresses in glulam frames / S. Ormarsson, Ó.V. Gíslason // European Journal of Wood and Wood Products. - 2016. - Vol. 74, Issue 3. - PP. 307-318.

9. Study of stress distribution and stress concentration factor in notched wood pieces with cohesive surfaces / J.R. Aira, T. Descamps, L. Van Parys, L. Léoskool // European Journal of Wood and Wood Products. - 2015. - Vol. 73, Issue 3. - PP. 325-334.

10. Проектирование конструкций из дерева и пластмасс / С.В. Поветкин, А.А. Сморчков, В.А. Кабанов, С.Ю. Табунов. - Курск: КПИ, 1993. - 93 с.

11. Smardzewski, J. Furniture design / J. Smardzewski. - Cham, Switzerland: Springer, 2015. - 649 p.

12. Ашкенази, Е.К. Анизотропия древесины и древесных материалов / Е.К. Ашкенази. - М.: Лесная промышленность, 1978. - 224 с.

13. Wood composites / ed. by M.P. Ansell. — Cambridge: Woodhead Publishing, 2015. — 437 p.

14. Ашкенази, Е.К. Анизотропия конструкционных материалов / Е.К. Ашкенази, Э.В. Ганов. - 2-е изд., перераб. и доп. - Л.: Машиностроение, 1980. - 248 с.

15. Светозарова, Е.И. Определение упругих констант клееной древесины / Е.И. Светозарова, А.В. Хапин // Изв. ВУЗов. Лесной журнал. - 1982. — № 3. - С. 63-66.

16. ГОСТ 16483.29-73. Древесина. Метод определения коэффициентов поперечной деформации. Введ. 01.01.1975. - М.: Изд-во стандартов, 1974. - 7 с.

17. Проектирование современных конструкций из клееной древесины на принципах новой концепции / В.З. Клименко, А.Я. Найчук, В.В. Фурсов, Д.В. Михайловский. - К.: Вид-во «Сталь», 2010. $-24 \mathrm{c}$.

\section{References}

1. Bogdanova, E.N. (2004). Analysis of the Causes of Building Collapse. Reinforcing Construction Methods (Analytical Report). Moscow: VNIINTPI.

2. Matiuschenko, D.M. Experimental and numerical investigations of glulam frames of glued wood. Scientific e-Journal of Chernihiv State Institute of Economics and Management. Series 2, Technique and Nature, 1, 92-99.

3. Klimenko, V.Z. (2009). The domestic experience of implementing the plywood structures into capital construction. Achievements and Problems. Budivnytstvo Ukrainy, 5, 17-21.

4. Mikhaylovskiy, D.V., \& Matyushchenko, D.N. (2015). Stress state bent frames, taking into account the anisotropy of the physical and mechanical properties of laminated wood. Construction, Materials Science, Mechanical Engineering, 81, 124-129.

5. SE "State Research Institute of Building Constructions". (2011). The constructions of buildings and structures. Design of timber structures. Common rules (DBN V.2.6-161:2010). Kyiv: Ministry for Regional Development, Building and Housing of Ukraine.

6. European Committee for Standardization. (2004). Eurocode 5: Design of Timber Structures. Brussels: BSI. 
7. Naichuk, A.Ya., Serov, E.N., \& Zakharevich, I.F. (2009). Some features of the calculation of glued wooden structures. In Proceedings of the International Symposium "Modern Metal and Wooden Structures: Standardization, Design, and Construction" (pp. 205-211). Brest: JSC "Brest Typography”.

8. Ormarsson, S., \& Gíslason, Ó.V. (2016). Moisture-induced stresses in glulam frames. European Journal of Wood and Wood Products, 74(3), 307-318. DOI:10.1007/s00107-016-1006-5

9. Aira, J.R., Descamps, T., Van Parys, L., \& Léoskool, L. (2015). Study of stress distribution and stress concentration factor in notched wood pieces with cohesive surfaces. European Journal of Wood and Wood Products, 73(3), 325-334. DOI:10.1007/s00107-015-0891-3

10. Povetkin, S.V., Smorchkov, A.A., Kabanov, V.A., \& Tabunov, S.Yu. (1993). Designing the Constructions of Wood and Plastic. Kursk: KPI.

11. Smardzewski, J. (2015). Furniture Design. Cham, Switzerland: Springer.

12. Ashkenazi, E.K. (1978). Anisotropy of Timber and Wood-Based Materials. Moscow: Les. Prom.

13. Ansell, M.P. (Ed.). (2015). Wood Composites. Cambridge: Woodhead Publishing.

14. Ashkenazi, E.K., \& Ganov, E.V. Anisotropy of Construction Materials ( ${ }^{\text {nd }}$ Ed.). Leningrad: Mashinostroenie.

15. Svetozarova, E.I., \& Khapin, A.V. (1982). Calculation of the elastic constants of glued wooden structures. Bulletin of Higher Educational Institutions: Lesnoy Zhurnal, 3, 63-66.

16. Ministry of Forest Industry of the USSR. (1974). Wood. Method for determination of factors of crosssectional deformation (GOST 16483.29-73). Moscow: Standards Publishing House.

17. Klimenko, V.Z., Naichuk, A.Ya., Fursov, V.V., \& Mikhaylovskiy, D.V. (2010). Designing the Modern Constructions of Plywood Based on a New Concept. Kyiv: Stal'. 